\title{
DISTINCTION OF APPLE CULTIVARS ACCORDING TO THEIR MAL D 1 ALLERGEN CODING GENES USING PCR TECHNIQUE
}

\author{
E.E. SZABÓ* and K. TAKÁCS \\ National Agricultural Research and Innovation Centre, Food Science Research Institute, \\ H-1022 Budapest, Herman Ottó út 15. Hungary
}

(Received: 13 September 2017; accepted: 11 June 2018)

Apple is one of the most important fruit grown and consumed in the temperate climate region. About $2 \%$ of the European population suffers from several allergenic reactions after consumption. Presence of 7 members of Mal d 1 gene family occurring in some apples was examined by PCR. The Mal d 1.01 and 1.02 genes could be detected from $91 \%$ and $79 \%$ of apple cultivars, respectively, due to the high degree of conservative regions. The Mal d 1.04 gene has 4 functional varieties and 2 pseudo-alleles, so it is highly variable. The PCR amplification with Mal d 1.06 primers gave one or two fragments with different sizes. The electrophoretic pattern is a suitable means to select apple cultivars according to their low, medium, or high Mal d 1 allergen content. Florina apple showed the single 154 bp allele, which is responsible for the small Mal d 1 allergen content in homozygote form.

Several samples gave weak signal or did not give any fragment-band on the gel, so Mal d 1.07 and 1.08 genes might have more varieties. Regarding the Mal d 1.09 gene we have found that it has conservative sequences in different apple cultivars and does not have too many varieties.

Keywords: Malus × domestica, Mal d 1 allergen family, PCR technique, apple allergy

Mal d 1 (originated from the Latin name of apple as Malus domestica) is one of the most important apple allergen families. Most of the birch pollen-allergic patients (50-70\%) in Central and Northern Europe suffer from different local symptoms, typically oral allergy symptoms (OAS) (BALLMER-WEBER, 2015). This allergenic reaction is based on the crossreaction between Mal d 1 and the most important birch pollen allergen, Bet v 1 (GeroLDINGERSimic et al., 2011).

The sequences of Mal d 1 and Bet v 1 were compared by VANEK-KREBITZ and co-workers (1995), and high degree of homology was demonstrated in amino acid (65.4\%) and nucleic acid (55.6\%) sequences. The Mal d 1 specific IgE antibodies are able to cross-react with, beside birch pollen allergen (Bet v 1), with celery (Api g 1), carrot (Dau c 1), cherry (Pru a 1), alder (Aln g 1), and peanut (Cor a 1) owing to sequence homology (EBNER et al., 1991).

The Bet v 1 and Mal d 1 proteins belong to PR-10 (pathogenesis related protein) family, which has important role in the defence of plants against biotic and abiotic stresses (ScHMITZEiberger \& MATTHES, 2011).

\footnotetext{
* To whom correspondence should be addressed.

Phone: +36 17960414 022; fax:+36 1796 0449; e-mail: koppanyne.szabo.erika@eki.naik.hu
}

This is an open-access article distributed under the terms of the Creative Commons Attribution-NonCommercial 4.0 International License (https://creativecommons.org/licenses/by-nc/4.0/), which permits unrestricted use, distribution, and reproduction in any medium for non-commercial purposes, provided the original author and source are credited, a link to the CC License is provided, and changes - if any - are indicated. 
Heat stabile allergenic proteins are responsible for the majority of food allergic reactions. By contrast, plant allergens giving cross-reaction with pollen allergens are heat labile proteins (e.g. Mal d 1). Their structure irreversibly changes under cooking, so they lose their allergenicity and become consumable for sensitized patients as well. Also, HsieH and coworkers (1995) found that the quantity of allergen proteins decreased at low temperature $\left(4{ }^{\circ} \mathrm{C}\right.$ ), and they could be inactivated by a 30 min-digestion with pepsin or trypsin (JENSENJAROLIS et al., 1999). Severity of allergic reactions to apple is not only related to the specific sensitivity of the individual, but also largely depends on the apple cultivar.

The Mal d 1 members are 17-18 kDa molecular-weight proteins and contain 158-159 amino-acids coded by 480-483 nucleotides (PueHringer et al., 2000). GAO and co-workers (2005) established that Mal d 1 family contains four subfamilies (I-IV) with 18 members.

Mal d 1.01 and Mal d 1.02 genes have highly conservative sequences in different apple cultivars. The Mal d 1.04 gene has more variable sequences with four functional variants and two pseudo alleles. In the case of Mal d 1.06 gene, three different variants are discovered. The existence of Mal d 1.07, Mal d 1.08, and Mal d 1.09 was demonstrated by GAO and coworkers (2005) in the near past, but the numbers of subfamilies have not been determined yet.

The target of the present work was to determine the occurrence of Mal d 1 proteincoding genes in some domestic apple cultivars. To achieve this purpose, we used primer pairs designed by GAO and co-workers (2005) to distinguish apple cultivars with low, medium, and high Mal d 1 allergen protein contents.

\section{Materials and methods}

\subsection{Samples}

Young leaves of twenty-four apple cultivars (see in Table 2) were collected at Research and Extension Centre for Fruit Growing, Újfehértó, Hungary. The samples were frozen $\left(-70{ }^{\circ} \mathrm{C}\right)$ in nylon sachets until analyses.

\subsection{DNA isolation and PCR amplification}

The DNA extraction and the PCR amplification were performed according to the methods described by Szabó and co-workers (2012). Primer sequences used for the PCR reactions were designed by GAO and co-workers (2005), the optimal parameters of the PCR reactions are presented in Table 1. DNA isolation and PCR reaction were performed in 3 parallel measurements in each case.

In case of Mal d 1.06 gene, PCR products were determined with Genetic Analyzer (ALFexpress) to identify the different fragment sizes.

\section{Results and discussion}

\subsection{DNA extraction}

Appropriate purity and quantity of extracted DNA are important prerequisites for PCR analysis. The R-values were between 1.7 and 2.0 for every sample, and the quantity of isolated DNA from the apple leaf was suitable for PCR analyses. 
Table 1. Parameters of PCR reaction used for the determination of different apple allergen coding genes

\begin{tabular}{|c|c|c|c|c|c|}
\hline Apple allergen & Denaturation & Annealing & Extension & Final extension & Cycle No. \\
\hline Mal d 1.01 & $\begin{array}{l}\text { (hot start): } 94{ }^{\circ} \mathrm{C}, 120 \mathrm{sec} \text {, then } \\
94{ }^{\circ} \mathrm{C} \text {, } 30 \text { sec }\end{array}$ & $58^{\circ} \mathrm{C}, 30 \mathrm{sec}$ & $72^{\circ} \mathrm{C}, 60 \mathrm{sec}$ & $72{ }^{\circ} \mathrm{C}, 5 \mathrm{~min}$ & 33 \\
\hline Mal d 1.02 & $\begin{array}{l}\text { (hot start): } 94{ }^{\circ} \mathrm{C}, 120 \mathrm{sec} \text {, then } \\
94{ }^{\circ} \mathrm{C}, 60 \mathrm{sec}\end{array}$ & $54{ }^{\circ} \mathrm{C}, 30 \mathrm{sec}$ & $72{ }^{\circ} \mathrm{C}, 60 \mathrm{sec}$ & $72{ }^{\circ} \mathrm{C}, 5 \mathrm{~min}$ & 35 \\
\hline Mal d 1.04 & $\begin{array}{l}\text { (hot start): } 94{ }^{\circ} \mathrm{C}, 120 \mathrm{sec} \text {, then } \\
94{ }^{\circ} \mathrm{C} 60 \mathrm{sec}\end{array}$ & $62{ }^{\circ} \mathrm{C}, 30 \mathrm{sec}$ & $72^{\circ} \mathrm{C}, 60 \mathrm{sec}$ & $72{ }^{\circ} \mathrm{C}, 5 \mathrm{~min}$ & 38 \\
\hline Mal d 1.06 & $\begin{array}{l}\text { (hot start): } 94{ }^{\circ} \mathrm{C}, 120 \mathrm{sec} \text {, then } \\
94{ }^{\circ} \mathrm{C} \text {, } 30 \text { sec }\end{array}$ & $60^{\circ} \mathrm{C}, 30 \mathrm{sec}$ & $72^{\circ} \mathrm{C}, 60 \mathrm{sec}$ & $72{ }^{\circ} \mathrm{C}, 5 \mathrm{~min}$ & 36 \\
\hline Mal d 1.07 & $\begin{array}{l}\text { (hot start): } 94^{\circ} \mathrm{C}, 120 \mathrm{sec} \text {, then } \\
94{ }^{\circ} \mathrm{C}, 60 \mathrm{sec}\end{array}$ & $58^{\circ} \mathrm{C}, 30 \mathrm{sec}$ & $72^{\circ} \mathrm{C}, 120 \mathrm{sec}$ & $72{ }^{\circ} \mathrm{C}, 5 \mathrm{~min}$ & 35 \\
\hline Mal d 1.08 & $\begin{array}{l}\text { (hot start): } 94{ }^{\circ} \mathrm{C} \text {, } 120 \mathrm{sec} \text {, then } \\
94{ }^{\circ} \mathrm{C} \text {, } 60 \text { sec }\end{array}$ & $55^{\circ} \mathrm{C}, 30 \mathrm{sec}$ & $72^{\circ} \mathrm{C}, 60 \mathrm{sec}$ & $72{ }^{\circ} \mathrm{C}, 5 \mathrm{~min}$ & 38 \\
\hline Mal d 1.09 & $\begin{array}{l}\text { (hot start): } 94^{\circ} \mathrm{C}, 120 \text { sec, then } \\
94^{\circ} \mathrm{C} \text {, } 30 \text { sec }\end{array}$ & $64{ }^{\circ} \mathrm{C}, 30 \mathrm{sec}$ & $72^{\circ} \mathrm{C}, 60 \mathrm{sec}$ & $72{ }^{\circ} \mathrm{C}, 5 \mathrm{~min}$ & 35 \\
\hline
\end{tabular}

\subsection{Determination of Mal $d 1.01$}

The 800 bp length fragment amplified by Mal d 1.01 primers was found in case of 22 samples, so these apple cultivars are likely to hold Mal d 1.01 gene (Table 2). Weak amplified fragments were obtained in case of Goldstar, Liberty, and Red Idared samples, which means that these cultivars probably contain small amounts of Mal d 1.01 allergenic protein coding gene.

Braeburn and Jonager apple cultivars did not give bands in the gel, so they might not have the examined gene at all. According to other options, since the Mal d 1.01 gene holds considerably conservative sequences, and have two different alleles, the Braeburn and Jonager apples are likely to hold the other Mal d 1.01 allele, which was not under analysis in this study.

Table 2. Conclusion of our results given by identification of Mal d 1 apple allergen coding genes

\begin{tabular}{clccccccc}
\hline No. & Apple cultivars & Mal d & Mal d & Mal d & Mal d & Mal d & Mal d & Mal d \\
& & 1.01 & 1.02 & 1.04 & 1.06 & 1.07 & 1.08 & 1.09 \\
\hline 1. & Regal Prince & + & - & + & ++ & + & $*$ & + \\
2. & Jonathan Csány 1 & + & - & + & ++ & + & - & + \\
3. & Red Jonathan & + & + & + & ++ & + & $*$ & + \\
4. & Red Spur Delicious & + & + & + & ++ & $*$ & - & + \\
5. & Elstar & + & + & + & ++ & + & + & + \\
6. & Braeburn & - & - & + & ++ & + & - & $*$ \\
7. & Charden & + & + & + & ++ & $*$ & $*$ & + \\
8. & Watson Jonathan & + & + & + & ++ & + & $*$ & + \\
9. & Rewena & + & + & + & ++ & $*$ & + & + \\
10. & Florina & + & + & + & + & $*$ & - & + \\
11. & Goldstar & $*$ & - & + & + & - & - & $*$ \\
12. & Liberty & $*$ & + & + & ++ & $*$ & + & + \\
13. & Angold & + & $*$ & + & + & + & + & + \\
\hline
\end{tabular}




\begin{tabular}{llccccccc}
\multicolumn{7}{c}{ Table 2. continued } \\
\hline No. & Apple cultivars & Mal d & Mal d & Mal d & Mal d & Mal d & Mal d & Mal d \\
& & 1.01 & 1.02 & 1.04 & 1.06 & 1.07 & 1.08 & 1.09 \\
\hline 14. & Golden Spur & + & $*$ & + & ++ & + & $*$ & + \\
15. & Jonager & - & - & - & + & - & - & - \\
16. & Rubinola & + & $*$ & + & ++ & $*$ & - & + \\
17. & Red Idared & $*$ & $*$ & $*$ & ++ & + & + & + \\
18. & Kr Óriás & + & $*$ & + & ++ & + & + & + \\
19. & Red Jonagold & + & + & + & ++ & + & + & + \\
20. & Burgundi & + & + & + & ++ & $*$ & + & + \\
21. & Gravenstein & + & + & + & ++ & + & + & + \\
22. & Alant apple & + & + & + & ++ & + & + & + \\
23. & Gala & + & + & + & ++ & + & + & + \\
24. & Regine & + & + & + & ++ & - & + & + \\
\hline
\end{tabular}

+: one fragment amplified; ++: polymorph pattern amplified; *: slight fragment amplified; -: no fragment amplified

\subsection{Determination of Mal d 1.02}

The results of PCR reaction showed the 723 bp length fragment amplified by Mal d 1.02 primers in case of 19 apple samples, so these cultivars may contain the Mal d 1.02 gene (Table 2). In case of Angold, Golden Spur, Rubinola, Red Idared, Kr Óriás apples we obtained a weak fragment-band owing to inadequate primer linkage due to the presence of different haplotypes.

Regal Prince, Jonathan Csány 1, Braeburn, Goldstar, and Jonager samples did not show bands at all. According to our assumption, these apple cultivars do not hold the amplified Mal d 1.02 gene. On the other hand, in spite that the Mal d 1.02 gene similarly to Mal d 1.01 gene has conservative sequences, there are more small differences in gene sequences as it has seven known haplotypes. We suppose that apple cultivars without fragment-bands are likely to contain one of the other unanalysed haplotypes, which was not determined.

\subsection{Determination of Mal d 1.04}

The 747 bp amplified fragment by the adapted 1.04 primer pair was obtained in case of 23 samples (Table 2). This result was unexpected, as according to the literature Mal d 1.04 genes show quite high variability in different apple cultivars. A weak fragment-band was obtained in case of Red Idared, due to inadequate primer binding or the fact that this cultivar contains only a small amount of Mal d 1.04 allergenic protein coding gene. The Jonager apple cultivar might contain one of the unexamined haplotypes from 4 functional variants or 2 pseudo alleles.

\subsection{Determination of Mal d 1.06}

According to GAO and co-workers (2005), the used primers are capable to discriminate between apple cultivars with small and big Mal d 1 allergen content, as the PCR amplification using Mal d 1.06 SSR-154 primer results polymorphic pattern of different 154, 156, 162, 164, and 174 bp fragments. It was established that those apple cultivars, which hold homozygote 154 bp fragment, might contain low amounts of Mal d 1 allergens. GAO and coworkers (2005) made skin prick test, too, on 100 selected apple allergenic patients as a 
confirmation of their results to demonstrate that there were differences among cultivars in Mal d 1-related allergenicity. So, this Mal d 1.06 SSR-154 primer can be used as marker primer to separate apple cultivars containing low amounts of allergenic proteins.

As, according to the literature, Mal d 1.06 genes have different polymorph patterns, Genetic Analyzer (ALFexpress) was used to determine the exact length of PCR fragments and even the small (1-2 bp) differences between PCR fragments given by Cy-5 labelled Mal d 1.06 SSR-154 primer pairs amplification. Table 3 shows that polymorphic pattern was detected for 20 apple cultivars. Among these 20 samples, the following 13 apple cultivars have the 154 bp length fragment in heterozygote form: Regal Prince, Jonathan Csány 1, Red Jonathan, Red Spur Delicious, Elstar, Braeburn, Watson Jonathan, Rewena, Liberty, Kr Óriás, Burgundi, Gravenstein, and Gala. As these samples contain another allele beside the 154 bp allele, the properties of the 154 bp allele might be modified by the other one. Seven out of the 20 samples did not have that 154 bp allele, they consist of mainly 156 and 162 bp fragments.

Exclusively, in homozygote form, only one examined apple variety - Florina - contained the 154 bp gene related to the low Mal d 1 allergen protein content. Goldstar, Jonager and Angold contain 156 bp and 162 bp allele, respectively, in homozygote form.

Table 3. The size of fragments given by amplification with Mal d 1.06 SSR primers

\begin{tabular}{|c|c|c|c|c|c|}
\hline No. & Apple cultivars & 154 bp & $156 \mathrm{bp}$ & 162 bp & $174 \mathrm{bp}$ \\
\hline 1. & Regal Prince & + & & + & \\
\hline 2. & Jonathan Csány 1 & + & & + & \\
\hline 3. & Red Jonathan & + & & + & \\
\hline 4. & Red Spur Delicious & + & & + & \\
\hline 5. & Elstar & + & & + & \\
\hline 6. & Braeburn & + & & + & \\
\hline 7. & Charden & & + & + & \\
\hline 8. & Watson Jonathan & + & & + & \\
\hline 9. & Rewena & + & & & + \\
\hline 10. & Florina & + & & & \\
\hline 11. & Goldstar & & + & & \\
\hline 12. & Liberty & + & & & + \\
\hline 13. & Angold & & & + & \\
\hline 14. & Golden Spur & & + & + & \\
\hline 15. & Jonager & & & + & \\
\hline 16. & Rubinola & & + & + & \\
\hline 17. & Red Idared & & + & + & \\
\hline 18. & Kr Óriás & + & & + & \\
\hline 19. & Red Jonagold & & + & + & \\
\hline 20. & Burgundi & + & + & & \\
\hline 21. & Gravenstein & + & & + & \\
\hline 22. & Alant apple & & + & + & \\
\hline 23. & Gala & + & & + & \\
\hline 24. & Regine & & + & + & \\
\hline
\end{tabular}

+: one fragment amplified 


\subsection{Determination of Mal d 1.07}

We could get the 266 bp amplified fragment by Mal d 1.07 primers at 21 apple cultivars, so these samples might hold Mal d 1.07 gene (Table 2). With the PCR amplification, 7 samples, Red Spur Delicious, Charden, Rewena, Florina, Liberty, Rubinola, and Burgundi, gave weak fragment-bands due to the inadequate primer binding or the presence of other Mal d 1.07 haplotypes. For Goldstar, Jonager, and Regine apple cultivars we did not obtain any fragmentband, as they did not contain Mal d 1.07 gene or supposedly had another Mal d 1.07 haplotype.

Summarizing these results, it can be concluded that Mal d 1.07 gene family is variable or has several haplotypes, as almost half of the apple cultivars gave weak fragment-band or no band in the gel.

\subsection{Determination of Mal d 1.08}

Only few data are available on the haplotypes of the Mal d 1.08 gene family similarly to Mal 1.07 gene-family.

Seventeen apple cultivars gave a 315 bp fragment amplified by Mal d 1.08 primers, so these apple cultivars might hold Mal d 1.08 gene (Table 2). Five out of 17 samples presented weak fragment-band (Regal Prince, Red Jonathan, Charden, Watson Jonathan, and Golden Spur) owing to inadequate primer binding or the presence of other Mal d 1.08 haplotypes. Seven apples (Jonathan Csány 1, Red Spur Delicious, Braeburn, Florina, Goldstar, Jonager, and Rubinola) did not give any fragment-band, so these apple samples are supposed to hold other Mal d 1.08 alleles or the quality of isolated DNA was not sufficient for PCR amplification.

\subsection{Determination of Mal d 1.09}

The 299 bp length PCR fragments given by amplification with the adequate primer pair were obtained for 23 apple cultivars, as they might hold Mal d 1.09 gene (Table 2).

Weak fragment-band was obtained for Braeburn and Goldstar apple cultivars due to the inadequate primer binding or the presence of different Mal d 1.09 haplotypes. No bands for Jonager cultivar could be detected as it probably holds a different Mal d 1.09 haplotype or the quality of the amplified DNA was not suitable.

It can be established that the Mal d 1.09 family probably do not have too many members, because a big number of apple samples amplified by Mal d 1.09 primer gave the 299 bp length fragment.

\section{Conclusions}

There are four known allergens in apple, from which the Mal d 1 are the major proteins responsible for the allergenic reactions especially in Northern Europe. We studied the occurrence of 7 main Mal d 1 (1.01; 1.02; 1.04; 1.06; 1.07; 1.08; 1.09) apple allergen coding genes in 24 different and most preferably consumed apple varieties, with PCR technique combined with agarose gel electrophoresis. Most members of Mal d 1 gene family could be detected from apple cultivars with the specific primers. Furthermore, with these techniques we could reveal the possible presence of additional haplotypes or varieties in Mal d 1.07 and 1.08 allergen families (GAO et al., 2005). By the means of Genetic Analyzer (ALFexpress) and using Mal d 1.06 SSR-154 primers, we could distinguish apple cultivars with low, 
medium, or high Mal d 1 allergen contents. With these results, we can promote the breeding of low allergen containing or allergen-free apple cultivars.

The Mal d 1 proteins can be eliminated by different thermal applications during apple processing in order to help the healthy diet.

\section{References}

Ballmer-Weber, B.K. (2015): Food allergy in adolescence and adulthood. Chem. Immunol. Allergy, 101, 51-58.

Ebner, C., Birkner, T., Valenta, R., Rumpold, H., Breitenbach, M., Scheiner, O., Kraft, D., Sakamoto, T., Hayashi, Y., Yamada, M., Torit, S., Urisu, A., Vieths, S., Schoning, B., Petersen, A., Janek, K., Aulepp, H., Rudeschko, O., Fahlbush, B., Henzgen,. M, Schlenvight, G., Herrmann, D. \& Jager, L. (1991): Common epitopes of birch pollen and apples: Studies by Western and Northern blot. J. Allergy Clin. Immun., 88, 588594.

Gao, Z.S., Van De Weg, W.E., Matos, C., Van Der Meer, I.M., Li, Y.H., Bolhaar, S.T.H.P., Knulst, A.C., Zuidmeer,. L, Van Ree, R., Hoffmann-Sommergruber, K. \& Gilissen, L.J.W.J. (2005): Allelic constitution of Mal d 1 genes on linkage group 16 is related to the differences in allergenicity among apple cultivars. Theor. Appl. Genet., 110, 769-783.

Geroldinger-Simic, M., Zelniker, T., Aberer, W., Ebner, C., Egger, C., Greiderer, A., Prem, N., Lidholm, J., Ballmer-Weber, B.K., Vieths, S. \& Bohle, B. (2011): Birch pollen-related food allergy: Clinical aspects and the role of allergen-specific IgE and IgG4 antibodies. J. Allergy Clin. Immun., 127, 616-622.

Hsien, L., Moos, M. \& LiN, Y. (1995): Characterization of apple 18 and 13 kD allegens by microsequencing and evaluation of their content during storage and ripening. J. Allergy Clin. Immun., 96, 960-970.

Jensen-Jarolis, E., Wiedermann, U., Ganglberger, E., Zurcher, A., Stadler, B.M., Boltz-Nitulescu, G., Scheiner, O. \& Breiteneder, H. (1999): Allergen mimotopes in food enchance type I allegic reaction in mice. FASEB J., 13, 1586-1592.

Puehringer, H., Moll, D., Hoffmann-Sommergrueber, K., Watillon, B., Katinger, H. \& Machado, M.L.D. (2000): The promoter of an apple Ypr10 gene, encoding the major allergen Mal d 1, is stress-and pathogen-inducible. Plant Sci., 152, 35-50.

Schmitz-Eiberger, M. \& Matthes, A. (2011): Effect of harvest maturity, duration of storage and shelf life of apples on the allergen Mal d 1, polyphenoloxidase activity and polyphenol content. Food Chem., 127, 1459-1464.

Szabó, E.E., Gelencsér, É., Kovács, E., Jánosi, A., TaKács, K. \& Kiss, E. (2012): Examinations of allergenic proteins coding genes of some domestic apple cultivars. Acta Alimentaria, 41, 8-18.

Vanek-Krebitz, M., Hoffmann-Sommergruber, K., Laimer Da Camara, M.M., Susani, M., Ebner, C., Kraft, D., Scheiner, O. \& Breiteneder, H. (1995): Cloning and sequencing of Mal d 1, the major allergen from apple (Malus domestica), and its immunological relationship to Bet v 1, the major birch pollen allergen. Biochem. Bioph. Res. Co., 214, 538-551. 